\title{
Neurological complications of measles
}

\author{
Padma S Gunaratne', T Rajendran' and S Tilakaratne'
}

(Index words: Acute post-infectious encephalitis, myelitis, CSF analysis).

\begin{abstract}
Objective To study the clinical features and course of neurological complications of measles.

Design Prospective study

Setting Neurology Unit, Teaching Hospital, Kandy

Patients 10 patients admitted with neurological complications of measles during an outbreak.

Mesurements Assessment of clinical features and the neurological investigations.

Results 6 had CSF IgM antibodies confirming a recent measles infection. 7 patients had encephalitis and 3 had myelitis. Complications had appeared 5 to 14 days after appearance of the rash. All patients with encephalitis had depressed level of consciousness (Glasgow coma scale 2 to 11 ) with seizures, 3 patients had lateralising signs, and assisted ventilation was required in 4. Cranial CTs were either normal or showed mild cerebral oedema. CSF analysis showed either normal or mildly raised protein without a cellular reaction. EEG in all 7 revealed diffuse delta activity. During the follow up period of 1 to 12 weeks, all showed a gradual improvement, except one who succumbed to respiratory complications of assisted ventilation. All others were left with some residual disability when last seen. Three patients with myelitis had symmetrical paraparesis. CSF protein was 60 to $80 \mathrm{mg} / \mathrm{ml}$ without a cellular reaction. All three improved without residual disability.
\end{abstract}

Conclusions Measles encephalitis is a life threatening complication. All three myelitis patients recovered completely within 5 to 8 weeks.

\section{Introduction}

An outbreak of measles occurred in Sri Lanka from September 1999 to May 2000. There were 2313 cases reported to the Epidemiological Unit of Department of Health Services in the first three months of the outbreak (1). The disease mostly affected children and adolescents. No accurate figures are available on the neurological complications that occurred in this outbreak. The general impression among clinicians probably underestimates the actual numbers (2).
The only previous report (3) of neurological complications of measles in Sri Lanka was during the outbreak that occurred in the Southern Province in 1990, which reported an incidence of $4.3 \%$ of acute encephalitis. This figure is 21 to 43 times the figures available for developed countries where the incidence of acute encephalomyelitis, which occurred 2 to 14 days after the appearance of the rash, is 1 to 2 per 1000 (4). The figure quoted for the developed countries is based on population studies, whereas the figure for Sri Lanka is based on hospital admissions, and many uncomplicated measles patients do not seek indoor treatment.

In this report we give the clinical and laboratory features of 10 patients who suffered neurological complications of measles during an outbreak.

\section{Case reports}

All 10 patients were seen in the Neurology Unit of the Teaching Hospital, Kandy. Four patients had been resident in Kandy and its vicinity. Four were referred from General Hospital Anuradhapura, and two from Teaching Hospital Kurunegala.

The clinical features of patients with acute encephalitis are given in Table 1 and those of patients with myelitis in Table 2.

There were 7 patients with encephalitis. All except two gave the typical history of measles (high fever, coryzal symptoms, conjunctivitis, and typical skin rash) several days before onset of neurological problems. Both patients without a history of measles were in their first trimester of pregnancy. All 7 had high fever on admission, and neck stiffness was present in 3. Funduscopic examination of all 7 were normal. Cranial CT was normal in 4 patients and showed evidence of cerebral oedema in three. 12-lead electroencephalography was carried out in 6 patients and all showed diffuse delta activity in all leads. CSF serology for Japanese B encephalitis was negative in all 7 patients.

There were 3 patients with myelitis following clinical measles. None had fever on admission or involvement of higher functions. Their upper limbs and respiratory muscles were spared. Lower limbs were flaccid and symmetrically weak, with intact sensory perception for all modalities. None required assisted ventilation.

\footnotetext{
'Department of Neurology, Teaching Hospital, Kandy. (Revised version accepted 17 February, 2001). Email: pagunara@slt.lk, Telephone +9408234220 (resid) + 9408222261 (off) for corresponding author, PSG.
} 
Table 1. Patients with encephalitis

\begin{tabular}{|c|c|c|c|c|c|c|c|}
\hline & Case 1 & Case 2 & Case 3 & Case 4 & Case 5 & Case 6 & Case 7 \\
\hline Age (years) & 32 & 15 & 9 & 6 & 5 & 17 & 24 \\
\hline Gender & $\mathbf{F}$ & $\mathbf{F}$ & $\mathbf{M}$ & $\mathbf{F}$ & $\mathbf{F}$ & $\mathbf{F}$ & $\mathbf{F}$ \\
\hline $\begin{array}{l}\text { Days from the } \\
\text { appearance of } \\
\text { rash }\end{array}$ & 8 & 10 & 10 & 7 & 5 & $\begin{array}{l}\text { No history } \\
\text { of rash }\end{array}$ & $\begin{array}{l}\text { No history } \\
\text { of rash }\end{array}$ \\
\hline Seizures & Partial & Partial & Generalised & Generalised & Generalised & Partial & Genemalised \\
\hline $\begin{array}{l}\text { *GC scale on } \\
\text { admission }\end{array}$ & $9 / 15$ & $7 / 15$ & $3 / 15$ & $11 / 15$ & $7 / 15$ & $7 / 15$ & $6 / 15$ \\
\hline $\begin{array}{l}\text { Motor response } \\
\text { of limbs to } \\
\text { sternal pressure }\end{array}$ & $\begin{array}{l}\text { Asymmetrical } \\
\text { flexion in } \\
\text { both sides }\end{array}$ & $\begin{array}{l}\text { Asymmetrical } \\
\text { flexion } \\
\text { in both sides }\end{array}$ & $\begin{array}{l}\text { Absent on } \\
\text { both sides }\end{array}$ & $\begin{array}{l}\text { Symmetrical } \\
\text { flexion on } \\
\text { both sides }\end{array}$ & $\begin{array}{l}\text { Symmetrical } \\
\text { flexion in } \\
\text { both sides }\end{array}$ & $\begin{array}{l}\text { Absent in } \\
\text { both sides }\end{array}$ & $\begin{array}{l}\text { Asymmetrical } \\
\text { flexion in } \\
\text { both sides }\end{array}$ \\
\hline $\begin{array}{l}\text { Assisted } \\
\text { ventilation }\end{array}$ & Required & Not required & Required & Not required & Required & Required & Not required \\
\hline CSF protein & $50 \mathrm{mg} / 100 \mathrm{ml}$ & $70 \mathrm{mg} / 100 \mathrm{ml}$ & $40 \mathrm{mg} / 100 \mathrm{ml}$ & LP failed & $60 \mathrm{mg} / 100 \mathrm{ml}$ & $40 \mathrm{mg} / 100 \mathrm{ml}$ & $50 \mathrm{mg} / 100 \mathrm{ml}$ \\
\hline CSF cells & $5 \mathrm{WBC} / \mu \mathrm{l}$ & $3 \mathrm{WBC} / \mu \mathrm{l}$ & $1 \mathrm{WBC} / \mu \mathrm{l}$ & LP failed & $5 \mathrm{WBC} / \mu \mathrm{l}$ & Nil & $3 \mathrm{WBC}_{\mu l}$ \\
\hline $\begin{array}{l}\text { Measles IgM } \\
\text { antibodies }\end{array}$ & Not available & Positive & Positive & Not available & Not available & Positive & Positive \\
\hline $\begin{array}{l}\text { Progression of } \\
\text { GC scale when } \\
\text { last seen }\end{array}$ & 13 at 1 week & 11 at 8 weeks & 15 at 12 weeks & 15 in 10 days & $\begin{array}{l}\text { Lost for } \\
\text { follow up }\end{array}$ & 15 at 4 weeks & 8 at 8 weeks \\
\hline Follow up & $\begin{array}{l}\text { Died of } \\
\text { respiratory } \\
\text { complications } \\
\text { of assisted } \\
\text { ventilation }\end{array}$ & $\begin{array}{l}\text { Had spontaneous } \\
\text { eye opening } \\
\text { localisation of } \\
\text { pain and made } \\
\text { incomprehensible } \\
\text { sounds }\end{array}$ & $\begin{array}{l}\text { Had normal } \\
\text { higher } \\
\text { functions and } \\
\text { spastic lower } \\
\text { limbs }\end{array}$ & $\begin{array}{l}\text { Recovered } \\
\text { without } \\
\text { leaving } \\
\text { residual } \\
\text { disability }\end{array}$ & $\begin{array}{l}\text { Transferred } \\
\text { for assisted } \\
\text { ventilation. } \\
\text { Slow } \\
\text { recovery. }\end{array}$ & $\begin{array}{l}\text { Had normal } \\
\text { higher functions } \\
\text { and } \\
\text { involuntary } \\
\text { movements } \\
\text { of hands }\end{array}$ & $\begin{array}{l}\text { Had left } \\
\text { hemiparesis, } \\
\text { spontaneous eye } \\
\text { opening and } \\
\text { inappropriate } \\
\text { verbal responses }\end{array}$ \\
\hline & \multicolumn{7}{|c|}{ - Glasgow coma scale } \\
\hline
\end{tabular}

Table 2. Patients with myelitis

Case $8 \quad$ Case 9

$\begin{array}{llll}\text { Age (years) } & 16 & 17 & 16 \\ \begin{array}{l}\text { Gender } \\ \text { Days from appearance of rash }\end{array} & \mathrm{M} & \mathrm{M} & \mathrm{F} \\ \begin{array}{l}\text { Power of lower limbs on admission } \\ \text { Peripheral motor and sensory }\end{array} & \text { Grade } 3 & 7 & 7 \\ \begin{array}{l}\text { conduction } \\ \text { Knee and ankle tendon reflexes }\end{array} & \text { Normal } & \text { Grade } 2 & \text { Grade } 2 \\ \text { Sphincter functions } & \text { Absent } & \text { Normal } & \text { Normal } \\ \text { CSF protein } & \text { Intact } & \text { Present } & \text { Present } \\ \text { CSF cells - lymphocytes per } \mu l & 80 \mathrm{mg} / 100 \mathrm{ml} & \text { Retention of urine } & \text { Retention of urine } \\ \text { Measles IgM antibodies } & 11 & 80 \mathrm{mg} / 100 \mathrm{ml} & 60 \mathrm{mg} / 100 \mathrm{ml} \\ \text { Time taken for full recovery } & \text { Positive } & 6 & 11\end{array}$




\section{Discussion}

Measles is diagnosed mainly on clinical features. This becomes more accurate during an epidemic (2). Demonstration of measles specific IgM antibodies, that persist for about a month after infection, confirms the clinical diagnosis (5). Isolation of measles virus from body secretions and complement fixation or haemagglutination tests are other ways of confirming the diagnosis (5). In 6 of our 10 patients the serology was positive for measles specific IgM antibodies. Diagnosis in 4 was based on the typical history of measles before onset of neurological complications.

Three types of neurological complications may occur with measles; acute post-infectious encephalitis, acute progressive infectious encephalitis and subacute sclerosing panencephalitis (SSPE) (6). Acute post-infectious encephalitis is the commonest, and occurs 2 to 14 days after appearance of the rash. It is thought to be caused by a direct attack of the virus on the brain. SSPE which occurs 5 to 10 years after measles infection is also due to viral persistence in brain cells. All 7 of our patients probably had immunologically mediated acute post-infectious encephalitis, because the onset of their illness was 5 to 14 days after appearance of the rash. All had clinical features of disseminated encephalitis, with altered higher functions, seizures and diffuse abnormality in EEGs. Three had partial seizures of whom two had lateralising signs.

In 3 patients the damage was mainly in the spinal cord. They had myelitis without clinical evidence of cerebral involvement, although no EEGs were performed in patients to assess subclinical cerebral involvement.

A gradual improvement of level of consciousness was seen in all patients with encephalitis except the one who died of respiratory complications of ventilation. However, the rate of improvement varied markedly. A 1955 study showed a mortality of $10 \%$ to $15 \%$ and permanent sequelae in about $20 \%$ of survivors of measles encephalitis (7). In our series, where the period of follow up varied from 1 to 12 weeks, all had residual disability of varying degree when last examined. But all patients who had myelitis improved rapidly within 5 to 8 weeks with no residual disability.

We have no information on the state of measles immunisation in our 10 patients. $50 \%$ were above the age of 15 years and it is unlikely that they were immunised, because mass measles immunisation of infants was started in Sri Lanka only 15 years ago. This may also account for the relatively high proportion of adults in our series.

The serious neurological complications that may occur in measles are sufficient reason for a more aggressive immunisation program. The presently recommended practice in Sri Lanka is a single dose of vaccine at the age of 9 months. This gives protection only to about 80 to $85 \%$ of those immunised. Since the present coverage rate in the public sector is about $90 \%$ of the infant population (2), it leaves about a quarter of the country's children without any immunity against measles. The two dose schedule of immunisation, which gives a much higher rate of immunity, combined with appropriate health education, would reduce the risk of the serious neurological complications of measles in the community.

\section{References}

1. Epidemiological Bulletin - Sri Lanka. Epidemiological Unit, Ministry of Health, 1999; 40: 4-5.

2. Lamabadusuriya SP, Senanayake $M$, Re-emergence of measles. Ceylon Medical Joumal 1999; 44: 185-6.

3. Lamabadusuriya SP, Jayantha UK. An outbreak of measles in the Southern Province. Ceylon Medical Journal 1992; 37: 46-8.

4. Brett EM, Paediatric neurology, 3rd edition. London: Churchill Livingstone, 1997: 647-50.

5. Collier L, Oxford J. Human virology: a text for students of medicine, dentistry and microbiology. Oxford: Oxford University Press, 1993: 115-16.

6. Norrby E, Kristensson K. Measles virus in the brain. Brain Research Bulletin 1997; 44: 213-20.

7. Greenberg M, Pellitterio, Eiscnistcin DT. Measles encephalitis 1. Prophylactic effect of gamma globulin. Journal of Paediatrics 1955; 46: 462-7. 